UDC 658.567: 662.75

\title{
DEVELOPMENT OF UTILIZATION METHODS AND RECYCLING OF EXPIRED TOXIC CHEMICALS
}

\author{
E.Sh.Mamedov, D.S.Veliyeva, T.N.Gulubeyova, A.E.Mamedov*, F.M.Aliyeva, \\ S.A.Huseynova, Z.S.Safaraliyeva \\ M.Nagiyev Institute of Catalysis and Inorganic Chemistry, NAS of Azerbaijan \\ *Institute of Control Systems, NAS of Azerbaijan \\ dilaraveliyeva49@gmail.com \\ Received 01.07.2019 \\ Accepted 30.10.2019
}

\begin{abstract}
Environmental pollution by hazardous chemicals is one of the global problems facing humanity. Most countries successfully handle these problems by developing recycling method. Recycling is a way of utilization as a result of which wastes are processed for repeated using. The aim of the work is to improve the known recycling methods of illiquid stocks of rocket fuel and its components and creation on their basis the simple economically reasonable, environmentally friendly and safe methods, i.e. processing of some types of fuels and components of rocket fuel that are not suitable for their intended use or more precisely oxidizers of rocket fuel - mélange- (AK-20k, AK-27i and AK-27p) and as well the rocket fuel "Samin", TM-185 and the one-component rocket fuel "Isonit".
\end{abstract}

Keywords: utilization, propellant, nitrate oxidizers «Melange», «Samin», «Isonit».

doi.org/10.32737/0005-2531-2020-2-48-55

\section{Introduction}

Study of neutralization method of toxic chemicals - components of propellant. The struggle against pollution by hazardous chemicals - wastes of chemical production, heavy industry, wastes of fuels etc. - has turned into one of the global challenges facing mankind. In world practice over the past 20 years substantial changes have occurred in waste management: from simple waste disposal to processing and reasonable recycling ways of resources. Recycling is a way of utilization as a result of which wastes are processed, producing goods, materials or substances suitable for their recycling. Recycling of materials ensures provision with raw material resources at the national and international level. Apart from economic benefits utilization of wastes makes a contribution to environmental protection, reduces carbon dioxide emissions etc.

As far back as in 90-es Europe has become actively engaged in processing and recycling of wastes and today has a powerful processing industry which is actively developing. Stimulus to economy is that utilization of secondary raw materials allows improving effectiveness of investments much more than application of primary resources. Processing and recycling of wastes significantly reduces pollution of waters and emis- sions of various hazardous substances to the atmosphere. Thus, recycling is a modern ecological technology plus a real saving. One of toxic and hazardous components of rocket fuel is nitrate oxidizer of fuel - Melange. It is highly aggressive and toxic (contains up to $22 \%$ of dinitrogen tetroxide dissolved in concentrated nitric acid), fireand explosive substance. The question of utilization of rocket fuel components must be considered in a comprehensive manner, i.e. utilization of fuel needs to be started along with utilization of oxidizer. Rocket fuel TG-02 «Samin» is a mixture of $50 \%$ of triethylamine and $50 \%$ of mixture of isomeric xylidines. It was determined that xylidines isolated from fuel «Samin» can be used as pesticides, but derivatives of 3,4-isomers of xylidine is a semi-product in the synthesis of vitamin $\mathrm{B}_{2}$. Xylidines are also a part of herbicide- pendimethalin, vulcanization accelerator, antioxidants, dyes and foaming agents in floatation of ores. Fuel OT-155 «Isonit» is an esterification product of isopropyl alcohol and nitric acid.

\section{Materials and methods}

Oxidizer AK and their utilization. One of toxic and hazardous components of rocket fuel is a nitrate oxidizer of melange. Use of nitrate oxidizers in military missile systems allows keeping them launch-ready for a long period $[1,2]$. Since now nitrate oxidizers have not 
been used in rocket engines and the use of fuels has changed, the storage of the significant amount of unused melange and fuels in warehouses from the end of the 80-es of the last century is extremely ecologically dangerous case. Melange is a highly aggressive and toxic (contains up to $22 \%$ of dinitrogen tetroxide dissolved in concentrated hydrogen nitrate) and fire and explosion (strong oxidizer, in contact with organic and combustible substances and heating causes inflammation followed by ignition with possible subsequent explosion) substance. Oxidizer vapors can cause poisoning in a human body through respiratory organs and skin integuments. Oxidizers on skin integuments and mucosae cause chemical burns of various degrees of severity. Skin hydration enhances lesion three times more than unmoistened skin. The first symptoms of acute poisoning with oxidizer vapors develop after their effect and are expressed by irritation in nasopharynx, with lacrimation, cough, difficulty in breathing, headache, and general weakness. In 0.5-1.0 hour the first symptoms disappear and after an open period (period of false wellbeing) continuing from 3 to 6 hours and more, the condition of victim can sharply worsen due to pulmonary edema. In less expressed cases initial symptoms of acute poisoning can go unnoticed. Due to high corrosion activity of nitrate oxidizers over time the container and capacities where oxidizers are stored, become useless and therefore wear level of containers makes the general situation extremely dangerous in areas of deployment of storage considering the climatic conditions (close groundwater occurrence, windiness). Environmental pollution at a direct threat to security personnel of warehouses and neighboring populations apparently occurs through penetration of RFC into atmosphere, soil and ground waters from unpressurized and worn-out storage facilities [3, 4].

Composition of some rocket oxidizers is the following:

- AK-20k: $80 \% \mathrm{HNO}_{3}, 20 \% \mathrm{~N}_{2} \mathrm{O}_{4}$, iodine inhibitor,

- AK-27i: $73 \% \mathrm{HNO}_{3}, 27 \% \mathrm{~N}_{2} \mathrm{O}_{4}$, iodine inhibitor,

- AK-27p: $73 \% \mathrm{HNO}_{3}, 27 \% \mathrm{~N}_{2} \mathrm{O}_{4}$, fluorine inhibitor.
Various additives in the mixture of dinitrogen tetroxide $\left(\mathrm{N}_{2} \mathrm{O}_{4}\right)$ are added into nitric acid to improve the exploitation properties of oxidizers. Nitric acid is mixed with water in any ratios, generating a large amount of heat. Dinitrogen tetroxide in nitric acid partially dissociates forming nitrogen dioxide which gives it brown color. Inhibitors are added to reduce corrosion effect of nitric acid by communications and equipment of rocket engine and reservoirs in which oxidizers are stored. Oxidizers based on nitric acid destroy most of nonmetallic materials: tree, rubber, many plastics, textiles, cardboard etc. They are hygroscopic, characterized by strongly expressed oxidizing properties and contain $65 \%$ of reactive oxygen, and high-toxic substances. Due to rather low boiling point of dinitrogen tetroxide $\left(22^{\circ} \mathrm{C}\right)$ these oxidizers are very volatile. Physical properties of these oxidizers are defined with the presence of nitric oxides and water in their composition. Main properties: from light yellow to brown; density at $15.6^{\circ} \mathrm{C}-$ $1.511-1.575 \mathrm{~g} / \mathrm{cm}^{3}$; boiling point $66-86^{\circ} \mathrm{C}$. Melange is utilized in two ways: 1) destruction (combustion). This method cannot be industrially realized for economic and ecological reasons; 2) processing of melange into products of industrial-technological purpose.

Original melange is dosed in water at 0 $5^{0} \mathrm{C}$ before achieving mass ratio of dinitrogen tetroxide in melange and water which is equal to $1: 5$. The mixture is kept at $0-5^{0} \mathrm{C}$. In water the process proceeds smoothly. This is due to the fact that water in this case is not only a reagent, but also a solvent, i.e. it occurs both as the interaction of dinitrogen tetroxide with water, and absorption of nitric acid in mélange by water. In case of non-compliance with dosage order of components the process becomes uncontrollable. During interaction of nitric oxides with water in melange nitric and nitrous acids are formed in small amounts, but nitric acid and water are formed during interaction of nitrous acid with hydrogen dioxide:

$$
\begin{aligned}
& \mathrm{N}_{2} \mathrm{O}_{4}+\mathrm{H}_{2} \mathrm{O} \rightarrow \mathrm{HNO}_{2}+\mathrm{HNO}_{3}, \\
& \mathrm{HNO}_{2}+\mathrm{H}_{2} \mathrm{O}_{2} \rightarrow \mathrm{HNO}_{3}+\mathrm{H}_{2} \mathrm{O} .
\end{aligned}
$$

Nitric acid is colorless clear liquid without mechanical mixtures non-fuming on air. 
Physical and chemical constants of nitric acid in neutralization process of oxidizers AK-20k, AK-27i, AK-27p were determined.

Utilization of nitric acid with production of products directed to agricultural application provides the vast and interesting prospects. The substantial experience exists globally in the production of fertilizers using nitric acid [5-7]. This includes processing of phosphorites to obtain nitrogen-phosphorus fertilizers, to produce $\mathrm{Na}$-, $\mathrm{K}$ - and Ca-saltpeter, and granulated ammonium nitrate. Moreover potassium nitrate contains two elements necessary for plants: nitrogen and potassium. Sodium-potassium nitrates are also applied in glassmaking and food industry for conservation of products. For example, protein content significantly increases in tested samples of potato when nitrogenous fertilizers containing melange is used. Amount of nitrates accumulated in potato tubers does not exceed current regional regulation. Nitric oxidizer is utilized by the reaction with carbonate calcium lime by the following scheme:

$$
\begin{aligned}
& \mathrm{H}_{2} \mathrm{O}+\mathrm{N}_{2} \mathrm{O}_{4} \rightarrow \mathrm{HNO}_{3}+\mathrm{HNO}_{2}, \\
& 2 \mathrm{HNO}_{3}+\mathrm{CaCO}_{3} \rightarrow \mathrm{Ca}\left(\mathrm{NO}_{3}\right)_{2}+\mathrm{H}_{2} \mathrm{CO}_{3} \\
& \mathrm{H}_{2} \mathrm{O} \quad \mathrm{CO}_{2}
\end{aligned}
$$

Fuel TG-02 «Samin». Utilization of rocket fuel components needs to be considered in a comprehensive manner, i.e. along with utilization of oxidizer it is necessary to start utilization of «Samin». Rocket fuel TG-02 is a mix of 50\% of triethylamine and $50 \%$ of isomeric xylidines.

\begin{tabular}{|c|c|c|c|}
\hline \multirow{2}{*}{ Indicator } & \multicolumn{3}{|c|}{ Oxidizer grade } \\
\hline & AK-20к & AK-27p & AK-27i \\
\hline Appearance & \multicolumn{2}{|c|}{ Mobile orange-brown liquid } & Mobile dark-cherry liquic \\
\hline Bubble point, ${ }^{0} \mathrm{C}$ & $49.0-56.2$ & $44.6-49.5$ & $44.4-48.7$ \\
\hline Crystallization point, ${ }^{\circ} \mathrm{C}$ & $\begin{array}{l}\text { from }-58.6 \\
\text { to }-65.0\end{array}$ & $\begin{array}{l}\text { from }-55.4 \\
\text { to }-61.0\end{array}$ & $\begin{array}{l}\text { from }-55.2 \\
\text { to }-61.2\end{array}$ \\
\hline $\begin{array}{l}\text { Density, } \mathrm{g} / \mathrm{cm}^{3} \text {, at } \\
20^{\circ} \mathrm{C} \\
50^{\circ} \mathrm{C}\end{array}$ & $\begin{array}{l}1.577-1.604 \\
1.528-1.551\end{array}$ & $\begin{array}{l}1.595-.616 \\
1.546-1.561\end{array}$ & $\begin{array}{l}1.596-1.611 \\
1.545-1.560\end{array}$ \\
\hline $\begin{array}{l}\text { Kinematic viscosity, cSt, at } \\
20^{\circ} \mathrm{C} \\
40^{\circ} \mathrm{C}\end{array}$ & $\begin{array}{l}1.0-1.1 \\
0.7-0.8\end{array}$ & $1.1-1.2$ & $1.1-1.3$ \\
\hline
\end{tabular}

This fuel is used as a rocket fuel with nitrate

Table 1. Main physical and chemical properties of oxidizers based on nitric acid oxidizers. TG-02 fuel ignites easily at contacts with nitric acid oxidizers with very small delays of self-ignition. It is hygroscopic, oxidized with air oxygen very slowly. The factors which catalyze the process are light, high temperature, moisture and presence of copper ions [8, 9]. «Samin» is characterized by physical and chemical properties which provide its reliable transportation and storage. This is a transparent liquid from yellow to light brown light with a boiling ranges of $80-120^{\circ} \mathrm{C}$. «Samin» belongs to the category of dangerous and poisonous products. Fuel causes poisoning with intake through respiratory organs, skin integument and gastrointestinal tract.

Maximum permissible concentration of its components in air of the work area in $\mathrm{mg} / \mathrm{m}^{3}$ : for xylidine -3 , for triethylamine -10 .

Xylidines. Xylidines (dimethylanilines) are colorless crystals or fluids with aniline odor which rapidly darken on air. They are wellsoluble in ethanol, diethyl ether, acetone, chloroform, benzene, limitedly - in water. Xylidines are typical aromatic monoamines similar to aniline. General formula of xylidines:<smiles>Cc1cccc(N)c1C</smiles>

There are 6 isomers with various positions of methyl groups that define their physical condition. 
Table 2. Main physical and chemical properties of fuel $\mathrm{Tg}-02$

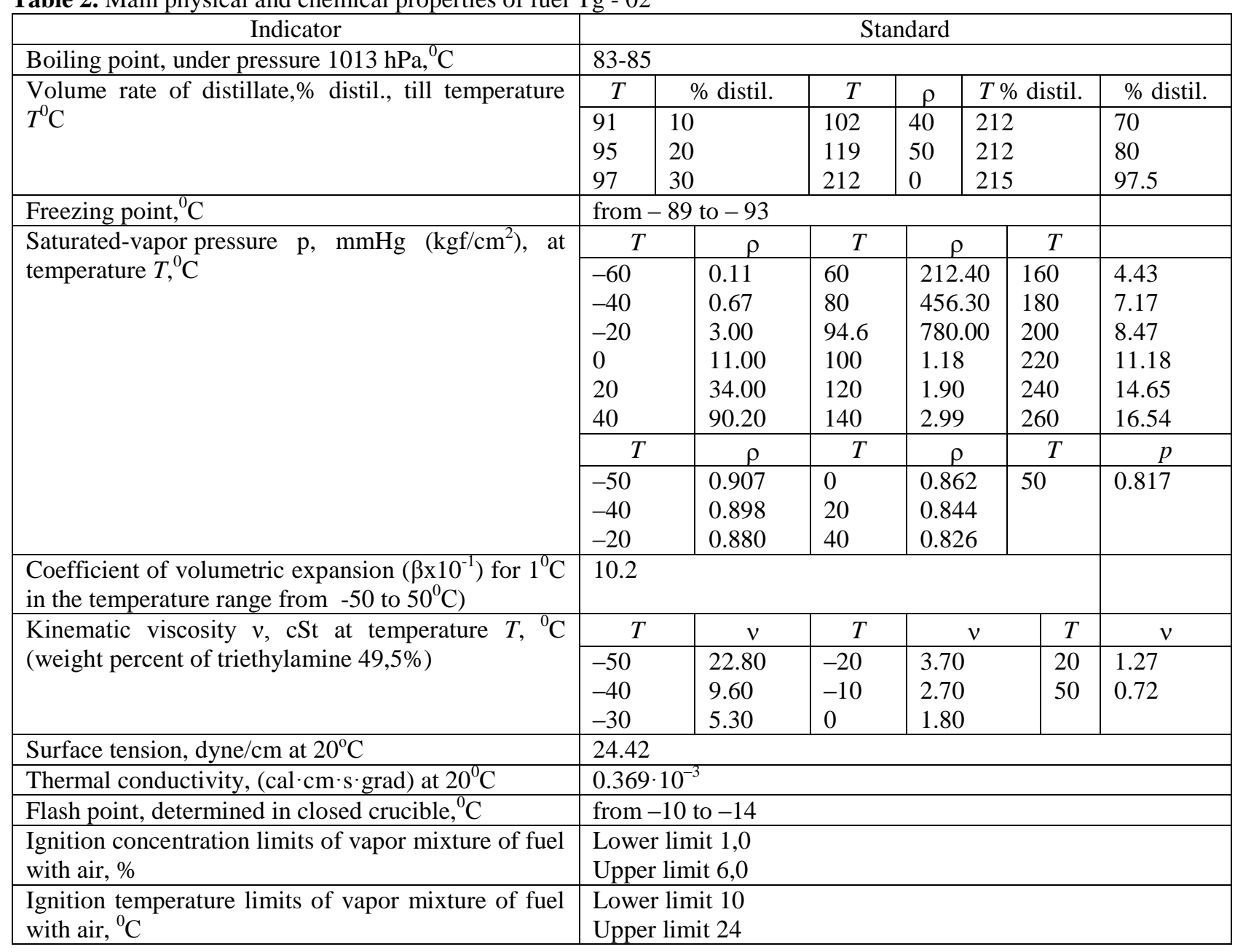

Table 3. Physical and chemical constants

\begin{tabular}{|c|c|c|c|}
\hline Name & $\begin{array}{c}\text { Specific weight, } \\
n_{D}^{20}\end{array}$ & $\begin{array}{c}T_{\text {melt }}, \\
{ }^{0} \mathrm{C}\end{array}$ & $\begin{array}{c}T_{\text {boil }}, \\
{ }^{0} \mathrm{C}\end{array}$ \\
\hline Xylidine-1,2,3 & 0.991 & liquid & $89^{0} \mathrm{C} / 10 \mathrm{mmHg}$ \\
\hline Xylidine-1,2,4 & 0.988 & liquid & $49^{0} \mathrm{C} / 10 \mathrm{mmHg}$ \\
\hline Xylidine-1,2,5 & - & 15.5 & $82^{0} \mathrm{C} / 10 \mathrm{mmHg}$ \\
\hline Xylidine-1,2,6 & 0.978 & liquid & $96^{0} \mathrm{C} / 10 \mathrm{mmHg}$ \\
\hline Xylidine-1,3,4 & - & 49 & $92^{0} \mathrm{C} / 10 \mathrm{mmHg}$ \\
\hline Xylidine-1,3,5 & 0.993 & liquid & \\
\hline
\end{tabular}

For example, 3,4-xylidine is a colorless crystal substance $\left(t_{\text {melt }} 51^{\circ} \mathrm{C}, t_{\text {boil }} 226^{\circ} \mathrm{C}\right)$. Other xylidines are colorless fluids with unpleasant odour which quickly darken on air, $t_{\text {melt }} 221-$ $217^{\circ} \mathrm{C}$ for xylidine- $1,2,6,220-221^{\circ} \mathrm{C}$ for $\mathrm{xy}-$ lidines-1,3,5. All xylidines are well-soluble in ethanol, diethyl ether, acetone, chloroform, benzene, limitedly - in water. Xylidines exhibit properties of aromatic amines: they form salts with mineral acids, with ethers, anhydrides and acid chlorides of carboxylic acids form $\mathrm{N}$-substituted amides, but with $\mathrm{HNO}_{3}$ they form diazonium salts.
Separation of xylidines from technical mixture is possible by studying their physical and chemical properties.

Mixture of isomeric xylidines (so called technical xylidine) containing $40-60 \%$ of xylidine-1,2,4 and $10-20 \%$ of xylidine-1.2,5 is divided with a fractional crystallization of salts. For example, xylidine-1,2,4 is extracted by processing $80 \%$ of acetic acid with subsequent filtration of acetate and washing out it with $20 \%$ of aqueous solution $\mathrm{NaOH}$. Xylidine-1,2,5 is extracted in the form of hydrochloride after 
separation of 1,2,4-isomer. 1,2,4- and 1,2,5xylidines used in the production of azo dyes and pigments are of most practical value. Xylidine$1,2,6$ is used in the synthesis of pesticides, $\mathrm{xy}$ lidine-1,3,4 - drug substances. Technical xylidine is a highly-active additive to aviation gasoline, vulcanization accelerator, antioxidant (for example, for wood), and foaming agent at flotation of ores. Ignition points for xylidines-1,2,4 and xylidine- $1,3,4$ are $93^{\circ} \mathrm{C}$ and $97^{\circ} \mathrm{C}$, correspondingly. Xylidines are widely used in automotive industry. Application of xylidines in gasoline up to $3 \%$ allows increasing octane value $12-15$ points. Density of xylidine at $20^{\circ} \mathrm{C}$ is $0.97 \mathrm{~kg} / \mathrm{m}^{3}$. Gasoline is prepared with an addition of xylidine by direct mixing of components using a simple method. Prepared gasoline is stable and meets all requirements for unleaded gasoline. Xylidines serve as antioxidants, foaming agents in flotation, they are used in the production of azo dyes.

Triethylamine. Triethylamine is a color- less low-viscosity fluid with a specific amine smell. It is sparingly soluble in water, well-soluble in acetone, mixes with ethanol. Triethylamine is used in the production of pesticides (for example, simazine, atrazine, cyanazine, etc.), corrosion inhibitors (for example, N,N-diethyl urea, dinitrobenzoate, diethylamine etc.), drug substances (for example, novocaine, cordiamine etc.), catalysts for synthesis of polyurethanes. Triethylamine is also used to produce antiseptics, wood, oligomers, and trichloroethylene stabilizers.

Monopropellant fuel OT-155 (Isonit). Fuel OT-155 is an etherification product of isopropyl alcohol and nitric acid. This is a mobile colorless and light yellow homogeneous liquid with ether odor.

Structural formula:

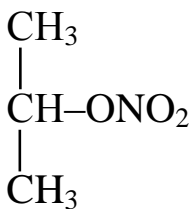

Table 4. Properties of xylidines

\begin{tabular}{|l|l|l|l|l|}
\hline \multicolumn{1}{|c|}{ Isomer } & \multicolumn{1}{|c|}{$T_{\text {melt }},{ }^{0} \mathrm{C}$} & \multicolumn{1}{|c|}{$T_{\text {boil }},{ }^{0} \mathrm{C}$} & \multicolumn{1}{c|}{$d_{4}^{20}$} & $n_{D}^{20}$ \\
\hline Xylidine 1,2,3 & -15 & $221 \quad 222$ & 0.9931 & 1.5684 \\
\hline Xylidine 1,2,4 & 16 & 214 & 0.9740 & 1.5569 \\
\hline Xylidine 1,2,5 & 15.5 & 213.5 & $0.9790\left(21^{0} \mathrm{C}\right)$ & 1.5591 \\
\hline Xylidine 1,2,6 & $11 \quad 12$ & $216 \quad 217$ & 0.9796 & 1.5612 \\
\hline Xylidine 1,3,4 & $51 \quad 226$ & $1.0769\left(17.5^{0} \mathrm{C}\right)$ & 1.5612 \\
\hline Xylidine 1,3,5 & 9.8 & $220 \quad 221$ & 0.9720 & 1.5581 \\
\hline
\end{tabular}

Table 5. Main physical and chemical properties of isonit (or - 155)

\begin{tabular}{|c|c|c|c|c|c|c|}
\hline Indicator & \multicolumn{6}{|c|}{ Standard } \\
\hline Freezing point, ${ }^{0} \mathrm{C}$ lower & \multicolumn{6}{|l|}{-60} \\
\hline Self-ignition temperature,${ }^{0} \mathrm{C}$ & \multicolumn{6}{|l|}{175} \\
\hline Flash point, defined in closed crucible, ${ }^{0} \mathrm{C}$ & \multicolumn{6}{|l|}{6} \\
\hline \multirow{2}{*}{$\begin{array}{l}\text { Saturated vapour pressure } \mathrm{p}, \mathrm{mmHg}\left(\mathrm{kgf} / \mathrm{cm}^{2}\right) \text {, at } \\
\mathrm{t},{ }^{0} \mathrm{C}\end{array}$} & $T$ & $P$ & $T$ & $P$ & $T$ & $P$ \\
\hline & $\begin{array}{c}-10 \\
0 \\
10 \\
20 \\
30\end{array}$ & $\begin{array}{l}7.3 \\
13.1 \\
22.5 \\
37.3 \\
59.9\end{array}$ & $\begin{array}{l}40 \\
50 \\
60 \\
70 \\
80\end{array}$ & $\begin{array}{l}93.2 \\
141.0 \\
208.4 \\
300.8 \\
425.4\end{array}$ & $\begin{array}{l}90.0 \\
98.1 \\
100.0 \\
110.0 \\
120.0\end{array}$ & $\begin{array}{l}590.2 \\
760.0 \\
804.0 \\
1079.0 \\
142.6\end{array}$ \\
\hline \multirow[t]{2}{*}{ Density $\mathrm{p}, \mathrm{g} / \mathrm{cm}^{3}$ at $\mathrm{t},{ }^{0} \mathrm{C}$} & $T$ & $\rho$ & $T$ & $\rho$ & $t$ & $\rho$ \\
\hline & $\begin{array}{l}-50 \\
-40 \\
-20 \\
\end{array}$ & $\begin{array}{l}1.1264 \\
1.1144 \\
1.0898 \\
\end{array}$ & $\begin{array}{l}0 \\
20 \\
40 \\
\end{array}$ & $\begin{array}{l}1.0657 \\
1.0416 \\
1.0160 \\
\end{array}$ & 50 & 1.0040 \\
\hline \multirow[t]{2}{*}{ Kinematic viscosity v, cST at $\mathrm{t},{ }^{0} \mathrm{C}$} & $T$ & $v$ & $T$ & $v$ & $T$ & $v$ \\
\hline & $\begin{array}{l}-40 \\
-20\end{array}$ & $\begin{array}{l}1.369 \\
0.951\end{array}$ & $\begin{array}{l}0 \\
20\end{array}$ & $\begin{array}{l}0.706 \\
0.580\end{array}$ & $\begin{array}{l}40 \\
60\end{array}$ & $\begin{array}{l}0.484 \\
0.407\end{array}$ \\
\hline Surface tension & \multicolumn{6}{|c|}{26.55} \\
\hline Explosion limit in mixture with air, volume ratio & \multicolumn{6}{|c|}{$\begin{array}{l}\text { Lower limit } 2 \\
\text { Upper limit } 100\end{array}$} \\
\hline
\end{tabular}


«Isonit» has relatively high energy properties. It is sensitive to external impacts (strike, beam, fire), low-soluble in water and well-soluble in alcohols, ethers, gasoline, kerosene, acetone and benzene. It is hygroscopic; crystallization of water may occur at low temperature. "Isonit" is noncorrosive in relation to aluminum and its alloys, low-carbon, carbon and stainless steels. However, on prolonged storage in moisture it can be hydrolyzed, therefore nitric and nitrogenous acids are formed which leads to the growth of corrosion activity of a fuel, especially in relation to low-carbon steel. Therefore, the product must be stored hermetically closed.

Irritation of upper respiratory tracts develops, headache, nausea occur in mild cases of intoxication. At a long stay in the atmosphere of fuel vapors low blood pressure joins these symptoms, further anemia develops. In severe cases sharp respiratory distress is observed, pulse becomes frequent, skin integuments and mucosas become blue, complete loss of consciousness occurs that can result in death. Fuel does not cause chemical burns of skin integuments. Maximum permissible concentration of isopropylnitrate in air of the work places is $5 \mathrm{mg} / \mathrm{m}^{3}$. "Isonit" used as a monofuel for driving turbine pump of anti-aircraft missile ZMV 2K11 "Krug" can be used as a solvent in paint and varnish and other industries after special processing.

Fuel TM-185. Fuel TM-185 is produced by mixing polymerdistillate (product of catalytic polymerization of unsaturated hydrocarbons of cracking gases) with light pyrolysis oil of kerosene-gasoil fraction and tricresol.

Despite the fact that separation process to initial components is not difficult, treatment of fractions for possible use of them in various industries is obligatory. Purification of light pyrolysis oil using aluminum chloride includes two operations - processing with aluminum chloride by separating wastes (complexes) and processing with alkali solution by separating alkaline wastes. These operations can be performed either in two different mixers which are sequentially switched on and placed usually one above another for outflow or in one general mixer. Sulfuric acid and aluminum chloride were used as a catalyst. Yield of resins raises with high consumption of $96 \%$ sulfuric acid, however, at a consumption of less than $2 \%$ melting point of resin decreases, therefore authors [9] consider that optimum value of acid consumption is $12 \%$ for a raw material exposed to polymerization. Optimum temperature of the process is $20^{\circ} \mathrm{C}$, higher temperature will decrease the yield of a resin and reduce its melting temperature. Optimum duration of contacting (during operation with sulfuric acid) is an hour; less duration decreases the yield of a resin and its melting temperature. Yield of a resin is $88 \%$ for light oil. A resin which can be used in a rubber and paint-and-varnish industry is produced when processing light pyrolysis oil with aluminum chloride. Technical polymer-distillate is a mixture of unsaturated hydrocarbons the content of which reaches $97 \%$. Unsaturated hydrocarbons give fuel insufficient resistance to oxidation by air oxygen during storage. Addition of light oil to polymerdistillate allows producing a fuel with higher density and resistance to oxidation by air oxygen. As an additive preventing crystallization of water at a negative temperature tricresol which is an ortho-, para-, and metacresol is added to fuel and produced by rectification of crude phenols of coal tar. Tricresol added to fuel is dehydrated under vacuum till the water content is not more than $0.03 \%$.

\section{Experimental part}

Recycling of nitrate oxidizer «Melange» and utilization of fuel TG-02 «Samin» are given as an example of utilization process of expired fuel components.

Utilization of mélange. $36 \mathrm{~g}(2.0 \mathrm{~mol})$ of water was loaded into a flask, cooled up to $2^{\circ} \mathrm{C}$, while stirring $67.3 \mathrm{~g}$ of melange was dosed at $0-5^{0} \mathrm{C}$. Upon completion of dosing of mélange the reaction mixture was kept for 15 minutes at this temperature. For completion of the reaction the temperature in the reactor was kept $5-10^{\circ} \mathrm{C}$ for an hour. Then the samples were taken and analyzed. Obtained nitric acid is a colorless transparent liquid without mechanical impurities non-fuming on air. $83.4 \mathrm{ml}(126 \mathrm{~g}, 2 \mathrm{~mol})$ of diluted nitric acid $(60 \%)$ is poured in portions into a flask with $100 \mathrm{~g}(0.1 \mathrm{~mol}) \mathrm{CaCO}_{3}$. Temperature in a flask was kept within $15^{\circ} \mathrm{C}$ throughout the process. 3 hours after the beginning of process sampling of reaction mixture was performed 
to determine acidity of the environment. Reaction ends when $\mathrm{pH}$ reaches the values 5.5-6.5 i.e. neutral state of a liquid product. By changing molar ratio of melange, water and temperature were defined: running of the process at higher temperatures that leads to the decrease in the yield of the target product to $92 \%$ against $96 \%$; running of the process at a certain concentration of acid.

Further for the implementation of the set task calcium nitrate which can be used as lime saltpeter is produced using the reaction of extracted nitric acid with calcium carbonate. Melange is added into the tank supplied with water (calculated amount) to dilute nitric acid till the necessary concentration (60\%). With such concentration acid exhibits the highest reactivity. Then acid is mixed with $\mathrm{CaCO}_{3}$ resulting in a liquid lime saltpeter $\mathrm{Ca}\left(\mathrm{NO}_{3}\right)_{2}$. Simplicity of instrumentation, reliability, high performance and environmental friendliness of the offered method allow solving an important problem - the placement of mobile installations directly on storage sites of mélange for elimination of the transportations of melange on long distances to the place of its processing.

Utilization of fuel TG-02. $500 \mathrm{ml}$ of fuel «Samin» is added into a flask supplied with reflux condenser and distillation was started. Triethylamine is separated at $78-82^{\circ} \mathrm{C}$. Refractive index $n_{D}^{20}-1.4003$ and specific weight -0.7821 are determined. Spectra NMR and UV are taken. The residue (mixture of xylidine isomers) is exposed to a vacuum distillation at $79-96^{\circ} \mathrm{C}(10 \mathrm{~mm} \mathrm{Hg})$, selecting each fraction separately.

\section{Conclusion}

According to the results of recycling of propellant components marketing research of the products was conducted for their recycling. In the reaction with calcium carbonate $\left(\mathrm{CaCO}_{3}\right)$ all types of nitric oxidizers are converted to calcium nitrate which is used in agriculture as a fertilizer.
It was defined that xylidines separated from fuel «Samin» can be used as pesticides, but derivatives of 3,4-isomer xylidine are semi-products in the synthesis of vitamin $\mathrm{B}_{2}$. Xylidines are also a part of herbicide - pendimethalin, vulcanization accelerators, antioxidants, dyes, foaming agents in flotation of ores. Triethylamine produced by distillation is used as a mineral fertilizer and a part of herbicides, dyes, and used in the production of plastics, resins, rubbers, drug substances (novocaine, cordiamine). Polymer resin which is used in rubber industry is produced in processing of light pyrolysis oil with aluminum chloride.

\section{References}

1. Pashkov G. L., Kuzmin V. I., Kononov Iu.S., Filatov Iu.T., Bogdanov S.G. Utilizatciia nekonditcionnykh okislitelei raketnogo topliva. Vestnik Sibirskogo gosudarstvennogo aerokosmicheskogo universiteta im. akademika M.F.Reshetneva. 2012. № 4. S. 174-179.

2. Zhidkoe raketnoe toplivo $\mathrm{v}$ regione OBSE: obzor aspektov utilizatcii. FSC.DEL/443/07/ Rev.2. Russian. 14-18. 2008.

3. Pat. 67466 Ukraina. Sposob pererabotki i okisleniia raketnogo topliva. Ableev A.G., Vakal S.V., Karpovich E.A. 2005.

4. Karpovich E.A., Vakal S.V., Zolotarev A.E., Drobat A.G. Sozdanie opytnoi ustanovki utilizatcii nekonditcionnogo okislitelia raketnogo topliva. Ekologiia i zdorove cheloveka. Okhrana vozdushnogo basseina. 2002. S. 31.

5. Akimova T., Kuzmin A. Utilizatciia othodov. Materialy XVI mezhdunar. nauchno-tekhn. konf. Harkov: Energostal, 2008. T. 2. S. 230-233.

6. Pashkov G.L., Kuzmin V.I., Kononov Iu.S. Filatov Iu.T. Bogdanov S.G. Razrabotka ishodnykh dannykh na proektirovanie ustanovki po utilizatcii okislitelia raketnogo topliva (melanzha) putem pererabotki na mineralnoe udobrenie, proizvoditelnostiu 1 tonna melanzha v chas: otchet GosNII MinDIP. Sumy, 2009.

7. Suvorov A. Sekretnoe goriuchee: Pishcha bogov. Populiarnaia mehanika. 2006. 11. R. 7-17

8. Chekalin M.A., Passet B.V., Ioffe B.A. Tekhnologiia organicheskikh krasitelei i promezhutochnykh produktov. L.: Himiia, 1980. $472 \mathrm{~s}$.

9. Melnikov H.H., Novozhilov K.V., Pilova G.N. Himicheskie sredstva zashchity rastenii (spravochnik). M: 1980. S. 255-256.

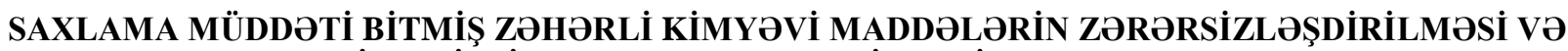 YENIDON ISTIFADə USULLARININ İŞLӘNIB HAZIRLANMASI
}

\author{
E.Sh.Məmmədov, D.S.Vəliyeva, T.N.Qulubəyova, A.E.Məmmədov, F.M.Oliyeva, S.A.Hüseynova, \\ Z.S.Səfərəliyeva
}

Retsiklinq (təkrar dövriyyə) - tullantı materialının təkrar istifadəsi üçün onun istənilən üsulla yenidən işlənməklə zərərsizləşdirilməsidir. Verilən işin məqsədi raket yanacaqları və onların komponentlərinin bəzi ləğ olunmamiş ehtiyatlarının ekoloji təmiz təhlükəsiz və iqtisadi əsaslandırılmış sadə yolla, yəni istifadə üçün yararsız olan bəzi növ raket 
yanacaqları və onların komponentlərinin işlənməsi, daha dəqiq desək raket yanacağının oksidləşdiricisi olan melanjin (AK-20k, AK-27u və AK-27p), həmçinin "Samin" raket yanacağının, TM-185 və bir komponentli raket yanacağı "İzonit"in zərərsizləşdirilməsi metodunun işlənilib hazırlanmasıdır.

Açar sözlor: zərərsizləşdirilmə, raket yanacă̆l, nitrat oksidloşdirici «Melanj», “Samin”, “İzonit”.

\section{РАЗРАБОТКА МЕТОДОВ УТИЛИЗАЦИИ И ПОВТОРНОГО ИСПОЛЬЗОВАНИЯ ЯДОВИТЫХ ХИМИЧЕСКИХ ВЕЩЕСТВ С ИСТЕКШИМ СРОКОМ ХРАНЕНИЯ}

\section{Э.Ш.Мамедов, Д.С.Велиева, Т.Н.Кулибекова, А.Э.Мамедов, Ф.М.Алиева, С.А.Гусейнова, 3.С.Сафаралиева}

Загрязнение окружающей среды вредными химическими веществами является одной из глобальных проблем, стоящих перед человечеством. Большинство стран успешно решает эти проблемы методом рециклинга. Рециклинг это любой способ утилизации, в результате которого материалы отхода подвергают переработке для их повторного использования. Целью данной работы является создание простого экономически обоснованного, экологически чистого и безопасного метода утилизации неликвидных запасов ракетных топлив и их компонентов, т.е. переработка некоторых видов топлив и компонентов ракетного топлива не пригодных для применения по назначению, а точнее окислителей ракетного топлива меланжа (АК-20к, Ак-27и и Ак-27p), а также ракетного горючего «Самин», ТМ-185 и однокомпонентного ракетного топлива «Изонит».

Ключевье слова: утилизация, ракетное топливо, азотнокисльй окислитель «Меланж», «Самин», «Изонит». 